\title{
A QUASI-CONTINUOUS RECORDER FOR OXYGEN AND CARBON DIOXIDE FOR CLINICAL ATMOSPHERE CONTROL ${ }^{1}$
}

\author{
By JESSE G. M. BULLOWA ANd GRACE LUBIN \\ (From the Medical Service, Harlem Hospital, and the Oxygen Research \\ Fund of New York University)
}

(Received for publication May 7, 1931)

Rapid and dependable methods of gas analysis are essential in the operation of tents and cubicles if specific concentrations of oxygen and carbon dioxide are to be maintained for treatment. From a clinical standpoint, chemical methods of analysis have the following distinct limitations. Unless tests are performed at very frequent intervals, a complete record of variations is not obtained. Individual. determinations are time consuming, usually requiring from 5 to 10 minutes, while the apparatus and solutions need frequent attention and their correct use involves considerable technical skill.

Recent application of the thermal conductivity method of gas analysis for automatically recording oxygen and carbon dioxide in air has greatly simplified the problem of clinical atmosphere control in the atmosphere control room operated at Harlem Hospital. Oxygen losses due to leaks, or accompanying the opening of the door, are promptly indicated on the recorder chart, and can thus be reduced to a minimum and compensated by increased flow, while the chart is obviously helpful in controlling decarbonation. The daily record promotes economy in operation as well as the safety of the patients, and, by providing an accurate check on the conditions of operation, it renders them less subject to human factors $(1,7)$.

Since thermal conductivity instruments, calibrated for the direct measurement of oxygen in air, and also for the measurement of carbon dioxide in the presence of high and fluctuating oxygen tensions, have

\footnotetext{
${ }^{1}$ Supported by the Committee for the Encouragement of Medical Research and the Littauer Pneumonia Research Fund of New. York University. 
hitherto been unavailable, a brief account will be presented of the instrument, its development and the method of its operation.

THERMAL CONDUCTIVITY METHOD OF GAS ANALYSIS

Within the past few years considerable impetus has been given to the technical development and industrial application of gas analysis methods based on differences in specific thermal conductivity. Indicating and recording instruments have been devised which detect the presence of an impurity in a given gas, or of quantitative variations in the composition of a gas mixture by means of changes in the temperature of an electrically heated platinum filament, which is surrounded by a thin layer of the gas to be tested. The lower the thermal conductivity of this gas, the greater will be its thermal insulating capacity, and hence the higher the equilibrium temperature and the electrical resistance of the filament.

The changes in the electrical resistance of the filament are directly referred to those of an identical filament, which is heated by the same current, but is insulated by a standard or reference gas mixture, and is contained in a separate compartment of the thermal cell. For purposes of comparison, the two filaments form adjacent arms of a Wheatstone bridge, the other two arms of the bridge being thermally indifferent manganin coils of approximately equal resistance, usually adjustable by means of a slide wire. If the bridge is balanced when the two compartments contain the same gas mixture (by adjustment of the slide wire or by some mechanical means of controlling the rate of heat loss from the platinum filaments) any difference between the composition of the mixture to be analyzed and the reference mixture will disturb the electrical balance of the bridge to an extent dependent on the difference between the thermal conductivities of the component gases as well as on the quantitative change in their relative proportions.

The thermal conductivity of the mixture is not always a linear function of the relative concentrations of the components. For water vapor in air, for example, the relation is far from linear, showing a distinct maximum at about 20 per cent water vapor (2). For carbon dioxide in air the relation appears to be linear at least up to 10 per cent carbon dioxide. For oxygen and nitrogen mixtures there are some apparent 
departures from a linear relation, possibly due to variations in the concentration of contaminating gases such as argon or hydrogen (3).

In the case of the Engelhard thermal cell, which was used in the present studies, the platinum filament is spiral in form and is fused into a quartz tube. It is claimed that the rigid support of the quartz insures a constant electrical resistance for a given temperature by eliminating variable factors due to the thermal expansion and contraction of the bare wire, with attendant changes in mechanical strain (3). To prevent the cooling action of a rapid flow of gas, only a small portion of the gas stream is by-passed through narrow openings into the thermal compartment proper.

The Engelhard cell has two devices for adjusting the cell readings to zero irrespective of whether the two compartments contain identical or different gas mixtures. One method consists in mechanically altering the rate of heat loss from one of the platinum filaments by a movable brass sleeve, referred to as the compensating plug. The sleeve can be raised or lowered by an adjusting screw, which is situated at the base of the compartment and is protected from air leakage by a screw cap. Raising the sleeve increases and lowering it decreases the rate of heat dissipation. The second method of balancing the Wheatstone bridge consists in changing the ratio of the balancing resistance wires by means of a slide wire screw, situated at the top of the cell.

A description of the Engelhard instrument, with emphasis on the present modification for oxygen and carbon dioxide, is given by Hamilton (3). Other types and makes of thermal conductivity cells are described by Knipping (5), Rabinowitch and Bazin (9), Palmer and Weaver (8) and Hill (4).

This physical method of analysis is not qualitative, serving merely to indicate quantitative changes in the proportions of the known ingredients of a gaseous mixture. Every instrument must be empirically calibrated with each type of mixture for which it is to be used.

In testing for variations of a component that is the only independent variable of a gas mixture, a single by-pass thermal cell may be used. In this type of cell the gas stream is drawn past only one of the two compartments of the cell, the "analysis" compartment, while a mixture of fixed composition is sealed in the other "reference" compartment. 
When the component to be measured is not the only independent variable, and the disturbing gases cannot be eliminated from the stream with suitable absorbents, a double by-pass cell must be used. In this type of cell the gas stream is by-passed through both compartments of the cell, but a scrubber is inserted before the reference compartment to remove completely the component, the concentration of which is to be measured.

\section{MEASUREMENT OF CARBON DIOXIDE AND OXYGEN IN AIR MIXTURE}

For the postulated reason that oxygen and nitrogen or air have closely similar thermal conductivities, and are thus not to be differentiated readily by the thermal conductivity method, suitably calibrated instruments have unfortunately not been hitherto available for the estimation of oxygen in air mixtures. The impression that oxygen and nitrogen are thermally indistinguishable appears to have been based upon the recorded thermal conductivity values at a temperature of $0^{\circ} \mathrm{C}$., which is considerably lower than the temperature actually obtaining in the thermal cells (about 75 or $80^{\circ} \mathrm{C}$.).

In Table 1 are presented Eucken's values for the thermal conductivi-

TABLE 1

Thermal conductivities of gases

\begin{tabular}{|c|c|c|c|c|}
\hline \multirow{2}{*}{ Gas } & \multicolumn{2}{|c|}{$k \times 10^{6}$} & \multicolumn{2}{|c|}{$\left(k_{\mathrm{air}}-k_{\mathrm{gas}}\right) \times 10^{6}$} \\
\hline & $0^{\circ} \mathrm{C}$. & $100^{\circ} \mathrm{C}$. & $0^{\circ} \mathrm{C}$ & $100^{\circ} \mathrm{C}$. \\
\hline 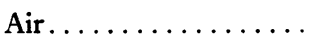 & 56.6 & 71.9 & & \\
\hline Argon.... & 38.8 & 50.9 & 17.8 & 21.0 \\
\hline Carbon dioxide. & 33.2 & 49.6 & 23.4 & 22.3 \\
\hline Nitrogen... & 56.8 & 71.8 & -0.2 & 0.1 \\
\hline Oxygen... & 57.0 & 74.3 & -0.4 & -2.4 \\
\hline
\end{tabular}

Sensitiveness ratio: $\frac{\mathrm{O}_{2} \text { in air }}{\mathrm{CO}_{2} \text { in air }}=\frac{k_{\mathrm{air}}-k_{\mathrm{O}_{2}}}{k_{\mathrm{air}}-k_{\mathrm{CO}_{2}}}=-0.017$ at $0^{\circ} \mathrm{C}$. and -0.108 . at $100^{\circ} \mathrm{C}$.

$k$ is the amount of heat in gram calories flowing per second through an area of $1 \mathrm{sq}$. $\mathrm{cm}$. with a temperature gradient of $1^{\circ} \mathrm{C}$. per $\mathrm{cm}$. It increases with the temperature but is almost independent of pressure. The values of $k$ are reproduced from Palmer and Weaver (8) and refer to experiments by Eucken. 
TABLE 2

Calibration tests for recorder

\begin{tabular}{|c|c|c|c|c|c|}
\hline \multicolumn{3}{|c|}{$\begin{array}{l}\text { Volumes per cent oxygen } \\
\text { January } 7-28,1931\end{array}$} & \multicolumn{3}{|c|}{$\begin{array}{c}\text { Volumes per cent carbon dioxide } \\
\text { April } 7,8,1931\end{array}$} \\
\hline $\begin{array}{l}\text { Recorder cell } \\
\text { no. } 28125\end{array}$ & $\begin{array}{l}\text { Chemical } \\
\text { analysis }\end{array}$ & $\begin{array}{c}\text { Correction for } \\
\text { recorder }\end{array}$ & $\begin{array}{l}\text { Recorder cell } \\
\text { no. } 29378\end{array}$ & $\begin{array}{l}\text { Chemical } \\
\text { analysis }\end{array}$ & $\begin{array}{l}\text { Correction for } \\
\text { recorder }\end{array}$ \\
\hline $\begin{array}{c}\text { volumes per cent } \\
0.05\end{array}$ & $\begin{array}{l}\text { volumes per cent } \\
\text { Nitrogen }\end{array}$ & $\begin{array}{l}\text { volumes per cent } \\
-0.05\end{array}$ & volumes per cent & volumes per cent & volumes per cent \\
\hline 17.5 & Room air & +3.3 & 0.01 & 0.00 & -0.01 \\
\hline 17.5 & Room air & +3.3 & 0.78 & 0.70 & -0.08 \\
\hline 18.5 & Room air & +2.3 & 0.78 & 0.70 & -0.08 \\
\hline 25.4 & 27.04 & +1.64 & 0.87 & 0.89 & +0.02 \\
\hline 25.7 & 26.67 & +0.97 & 0.88 & 0.90 & +0.02 \\
\hline 31.3 & 31.5 & +0.20 & 1.09 & 1.11 & +0.02 \\
\hline 31.4 & 31.9 & +0.50 & 1.11 & 1.10 & -0.01 \\
\hline 31.6 & 31.8 & +0.20 & 1.18 & . 1.10 & -0.08 \\
\hline 34.8 & 33.5 & -1.30 & 1.22 & 1.25 & +0.03 \\
\hline 35.0 & 33.7 & -1.3 & 1.23 & 1.29 & +0.06 \\
\hline 35.7 & 34.6 & -1.1 & 2.52 & 2.51 & -0.01 \\
\hline 40.3 & 38.6 & -1.7 & 2.53 & 2.54 & +0.01 \\
\hline 40.5 & 38.96 & -1.54 & 5.03 & 5.10 & +0.07 \\
\hline 41.5 & 39.76 & -1.74 & & & \\
\hline 41.6 & 39.7 & -1.9 & & & \\
\hline 42.0 & 39.3 & -2.7 & & & \\
\hline 49.8 & 45.6 & -4.2 & & & \\
\hline 50.1 & 45.7 & -4.4 & & & \\
\hline 50.2 & 46.2 & -4.0 & & & \\
\hline 50.3 & 45.3 & -5.0 & & & \\
\hline 54.9 & 50.3 & -4.6 & & & \\
\hline 54.9 & 50.15 & -4.75 & & & \\
\hline 61.5 & 55.42 & -6.08 & & & \\
\hline
\end{tabular}

ties of air, oxygen, nitrogen and carbon dioxide at $0^{\circ}$ and $100^{\circ} \mathrm{C}$. (8). It will be seen that the values for oxygen and air are almost indistinguishable at $0^{\circ}$, but show a greater divergence at $100^{\circ}$. At the higher temperature the difference between oxygen and air is about one-tenth of that obtaining between carbon dioxide and air. The ratio has a negative sign, because the thermal conductivity of oxygen is higher, while that of carbon dioxide is lower than the value for air.

Thermal conductivity instruments of the single by-pass type are available for the estimation of carbon dioxide in air to within about \pm 0.05 parts per hundred, among others, the Engelhard, the Brown, and the Leeds and Northrup carbon dioxide recorders and the "ka- 
tharometer" of the Cambridge Instrument Co. On the basis of the ratio quoted above, it is somewhat surprising that no attempt has been made to adapt these instruments as oxygen in air recorders, having an accuracy of about 0.5 per cent. A single exception, of theoretical rather than practical interest, may be mentioned. Ledig and Lyman (6) describe a thermal conductivity oxygen in air indicator, constructed for respiratory studies under the auspices of the Bureau of Standards. The results obtained with this instrument agreed with chemical analyses to within 0.05 per cent for both oxygen and carbon dioxide. Because of the extreme delicacy of the oxygen cell and bridge used in this case, the instrument was subject to many disturbing factors and could not be converted into a continuous recorder.

Not only has the thermal conductivity method been unavailable for oxygen in air measurements, but in addition, when the method was applied to carbon dioxide measurements, the disturbing effect of a varying oxygen-nitrogen ratio was in general neglected. According to the value of the ratio $\left(\frac{k_{\mathrm{air}}-k_{\mathrm{O}_{2}}}{k_{\mathrm{air}}-k_{\mathrm{CO}_{2}}}\right)_{100^{\circ} \mathrm{C} \text {. }}$ shown in Table 1, a single by-pass carbon dioxide cell with ordinary air sealed in the reference compartment should show an error of about 1 per cent in the carbon dioxide reading for a 10 per cent change in oxygen concentration, increase in oxygen appearing as an apparent decrease in carbon dioxide, and vice versa. Neglect of this source of error is justified only by virtue of the usual constancy of the carbon dioxide-oxygen ratio in industrial and in metabolic conditions, when the instrument has been calibrated under the conditions for which it is to be used. In this connection it should be mentioned that although Ledig and Lyman followed the general custom of using a single by-pass cell for carbon dioxide in air measurements, they nevertheless recognized the disturbing effect of a varying oxygen-nitrogen ratio, and compensated for this source of error by special correction factors.

\section{DEVELOPMENT OF OXYGEN RECORDER}

The development of a practical recorder for carbon dioxide and oxygen in air occurred in the following way. In 1928 a carbon dioxide recorder with a scale adjusted to read the carbon dioxide directly, up to a maximum of ten per cent, was made available for the use of one of us through the courtesy of Charles Engelhard, Inc., of Newark, N. J. The instrument was 
of the usual single by-pass type, and was intended for alveolar air studies on patients receiving oxygen-enriched air. When the apparatus proved unsuitable for this purpose owing to the time lag involved, and also because of the then unsuspected effect of the oxygen, it was continued in use as a part of the equipment of the atmosphere control room for pneumonia patients at Harlem Hospital, to provide a continuous record of the carbon dioxide content of the air.

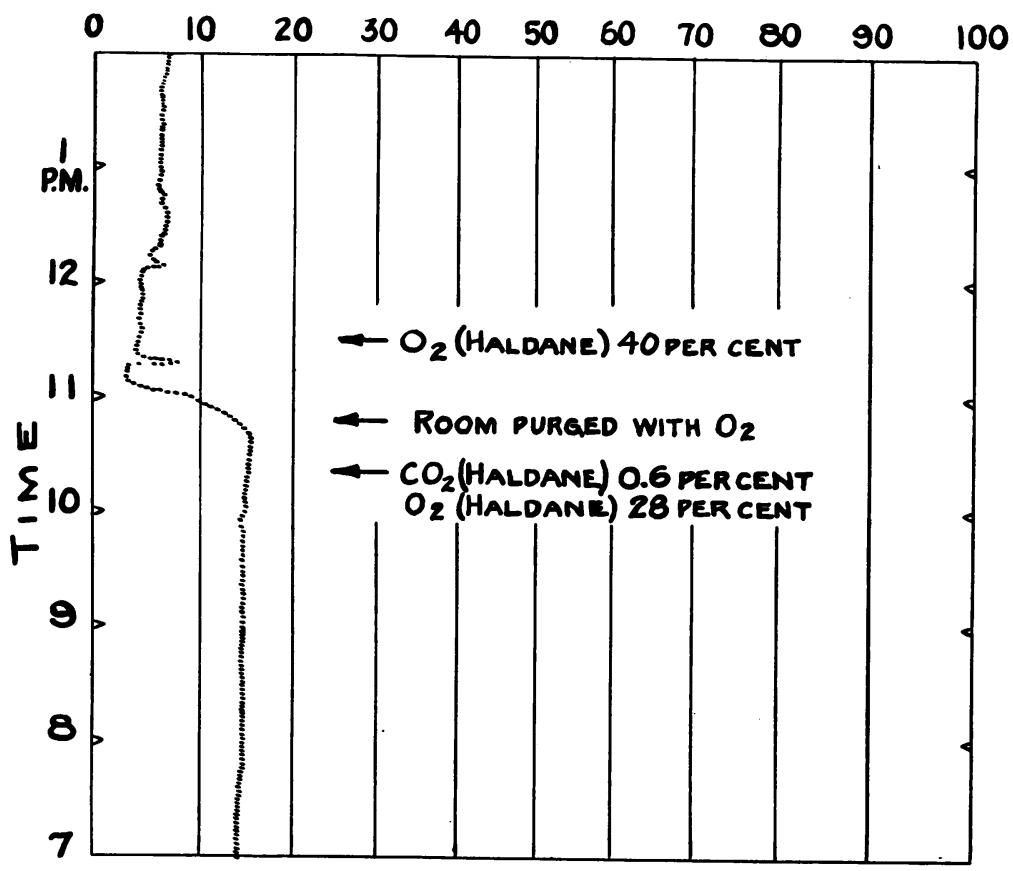

Fig. 1. Inaccurate Carbon Dioxide Record (Parts Per Mille) from Oxygen Chamber with Single By-Pass Cell

Here again the fluctuating oxygen concentration in the oxygen room rendered the instrument useless as a carbon dioxide recorder. Figure 1 shows a typical example of the inaccurate curves obtained in June, 1929. It will be seen that the recorder shows 1.5 per cent carbon dioxide as opposed to 0.6 by chemical analysis. The oxygen concentration, determined chemically at the same time, was 28 per cent.

By means of the special compensating plug with .which this particular type of instrument is equipped (see page 605), the cell had been adjusted so as to give zero deflection when the analysis compartment contained dry carbon dioxide-free air drawn from the oxygen room and containing a high but undetermined oxygen content, while the reference compartment con- 
tained ordinary dried air, free from carbon dioxide. We can roughly estimate this undetermined oxygen concentration from the error in the recorded carbon dioxide. Assuming a sensitivity ratio of roughly 8 to 1 for carbon dioxide and oxygen respectively, as was indicated by subsequent tests with this instrument, the oxygen concentration at which the instrument had been originally balanced was probably about $28+8(1.5-0.6)=35.2$ per cent. Departures from this original oxygen concentration affected the accuracy of the carbon dioxide readings, a lower oxygen concentration giving too high a reading and a higher oxygen concentration having the opposite effect.

The above interpretation of the readings shown by the supposed carbon dioxide recorder was not made until December, 1929, when the anomalous results obtained were studied more closely. At that time Engelhard, Inc., readjusted the instrument by means of the compensating plug to give a zero deflection when the analysis compartment contained ordinary dry carbon dioxide-free air. Subsequent tests with dry room air (20-21 per cent oxygen) enriched with carbon dioxide showed results in agreement with Haldane determinations of the carbon dioxide. When the instrument was later connected with the dried oxygen-enriched air of the atmosphere control room, however, a negative deflection of the galvanometer was obtained, in spite of the presence of about 1.0 per cent of carbon dioxide. After testing for possible disturbing factors, such as leaks in the pipe lines, or insufficient dehydration of the air current, we notified the Engelhard laboratory of the apparently inaccurate results, for which they were unable to account.

It then occurred to us that the instrument might be more sensitive to variations in oxygen concentration than had been generally assumed to be the case. To test our supposition, it was necessary to observe the free deflection of the instrument in the presence of a varying oxygen concentration and under constant conditions of moisture and carbon dioxide. Since increase in oxygen apparently induced a negative deflection, and since the mechanical construction of the galvanometer prevented the index from swinging over more than two or three scale divisions below zero, the compensating plug of the cell was turned to unbalance the bridge, causing the recorder index to come to rest at about $65 / 100$ of a full scale deflection with ordinary dry carbon dioxide-free air in both the analysis and the reference compartments of the cell. When a stream of dried carbon dioxide-free air containing about 40 per cent oxygen was drawn through the analysis compartment from the oxygen room, the galvanometer index retreated to the left, as may be seen in Figure 2. The instrument appeared capable of registering a slight loss of oxygen when the nurse's lock to the oxygen room was opened, as well as the effect of increasing the rate of oxygen delivery to the room. When connected to an oxygen cylinder, a much more marked negative deflection was obtained. Calibration with a Binger absorption apparatus indicated that the sensitiveness toward oxygen was roughly one- 


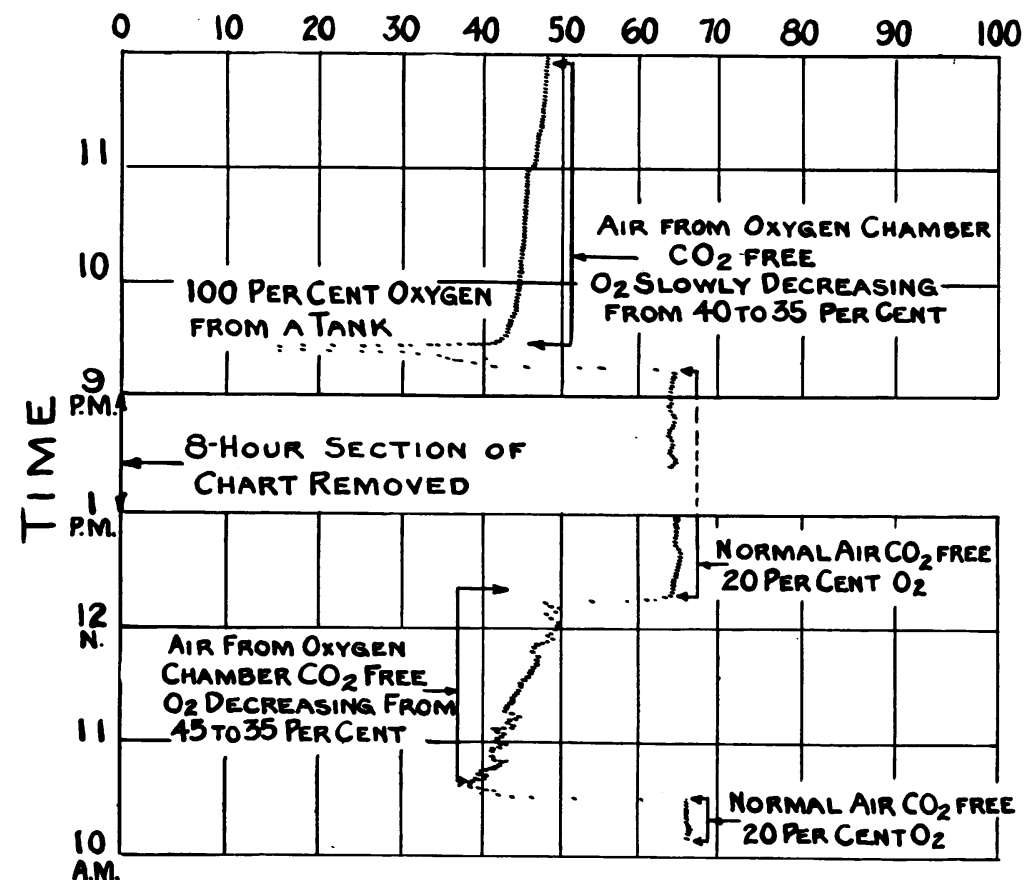

Fig. 2. Effect on Single By-Pass Cell of Variations in Oxygen Concentration

eighth of that shown in the opposite direction toward carbon dioxide. It is of interest to note the close correlation between the sensitivity ratio as determined empirically, $\frac{\mathrm{O}_{2} \text { in air }}{\mathrm{CO}_{2} \text { in air }}=-1 / 8$, and the ratio calculated from the thermal conductivity values given in Table 1 for $100^{\circ} \mathrm{C}$., namely, $\frac{\mathrm{O}_{2} \text { in air }}{\mathrm{CO}_{2} \text { in air }}=-2.4 / 22.3=-1 / 9.3$.

Since an accuracy of \pm 1.0 or 2.0 per cent is quite adequate for the oxygen control in the clinical chamber, the doubly practical significance of our observations became at once apparent. In the first place, the single by-pass cell, with galvanometer leads reversed, appeared capable of functioning as an oxygen recorder for air freed from moisture and carbon dioxide. In the second place, a cell of this type would be useless for carbon dioxide determinations of the air from the oxygen room. For this purpose a double by-pass cell should be used, the standard compartment of which should receive dried carbon dioxide-free air having the same oxygen-nitrogen ratio as is present in the dry air drawn through the analysis compartment. 


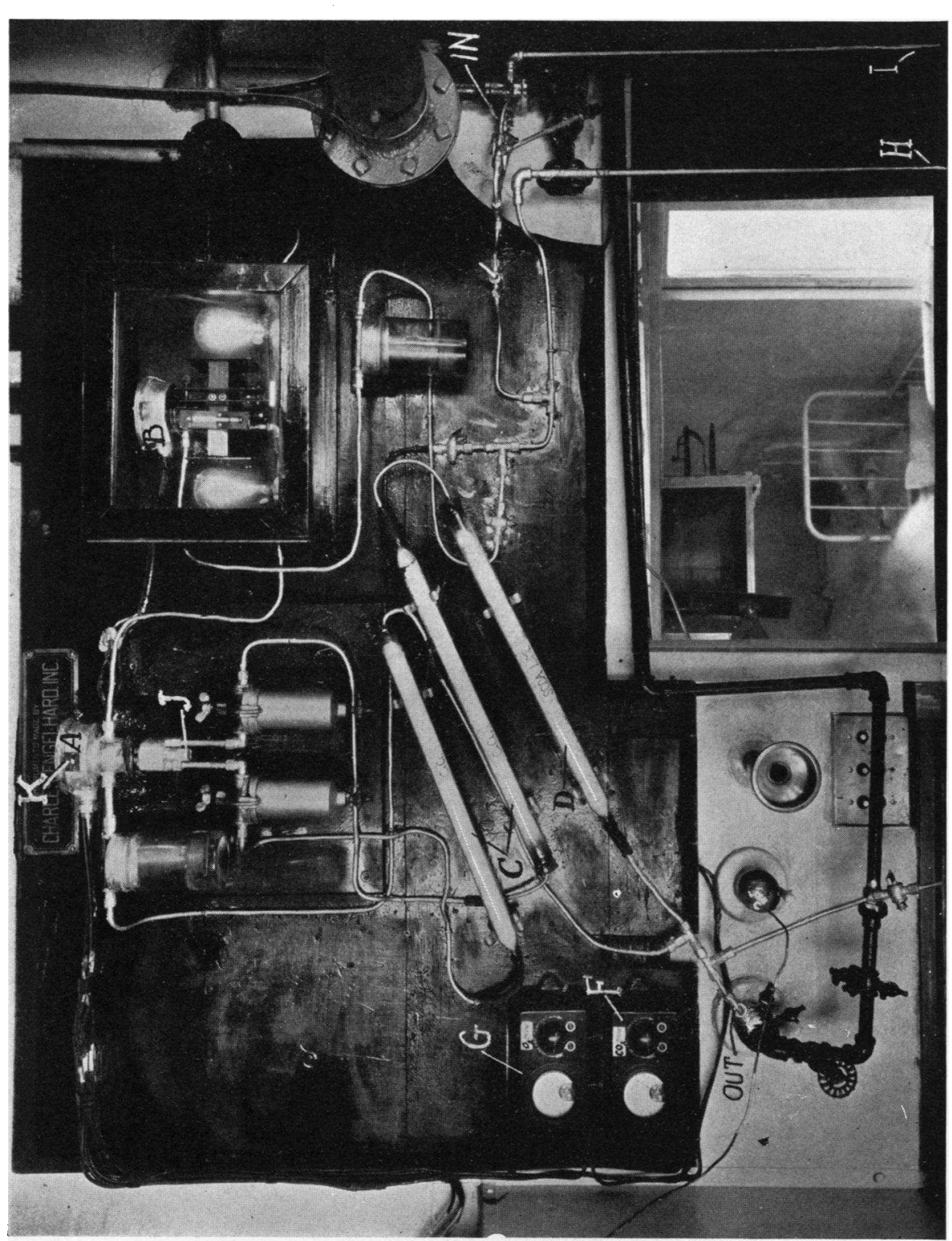

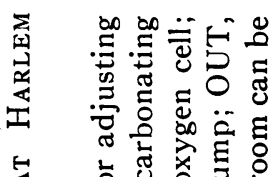

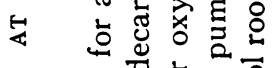

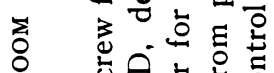

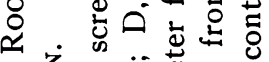

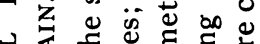

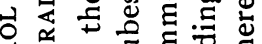
F

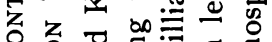

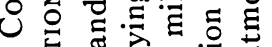
필

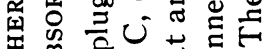

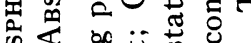

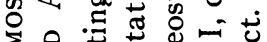

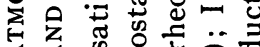

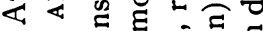

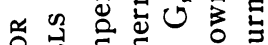

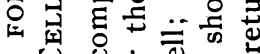

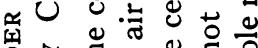

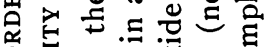

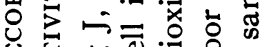
舟 政 50 云

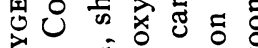

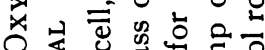

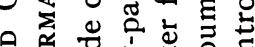

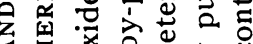
Fث. 똿

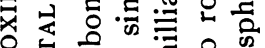

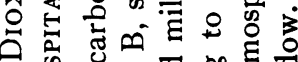
of of of of

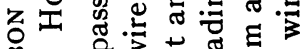
品

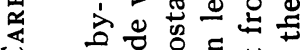
U 0 ๓

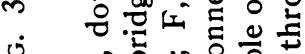

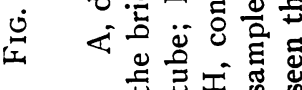




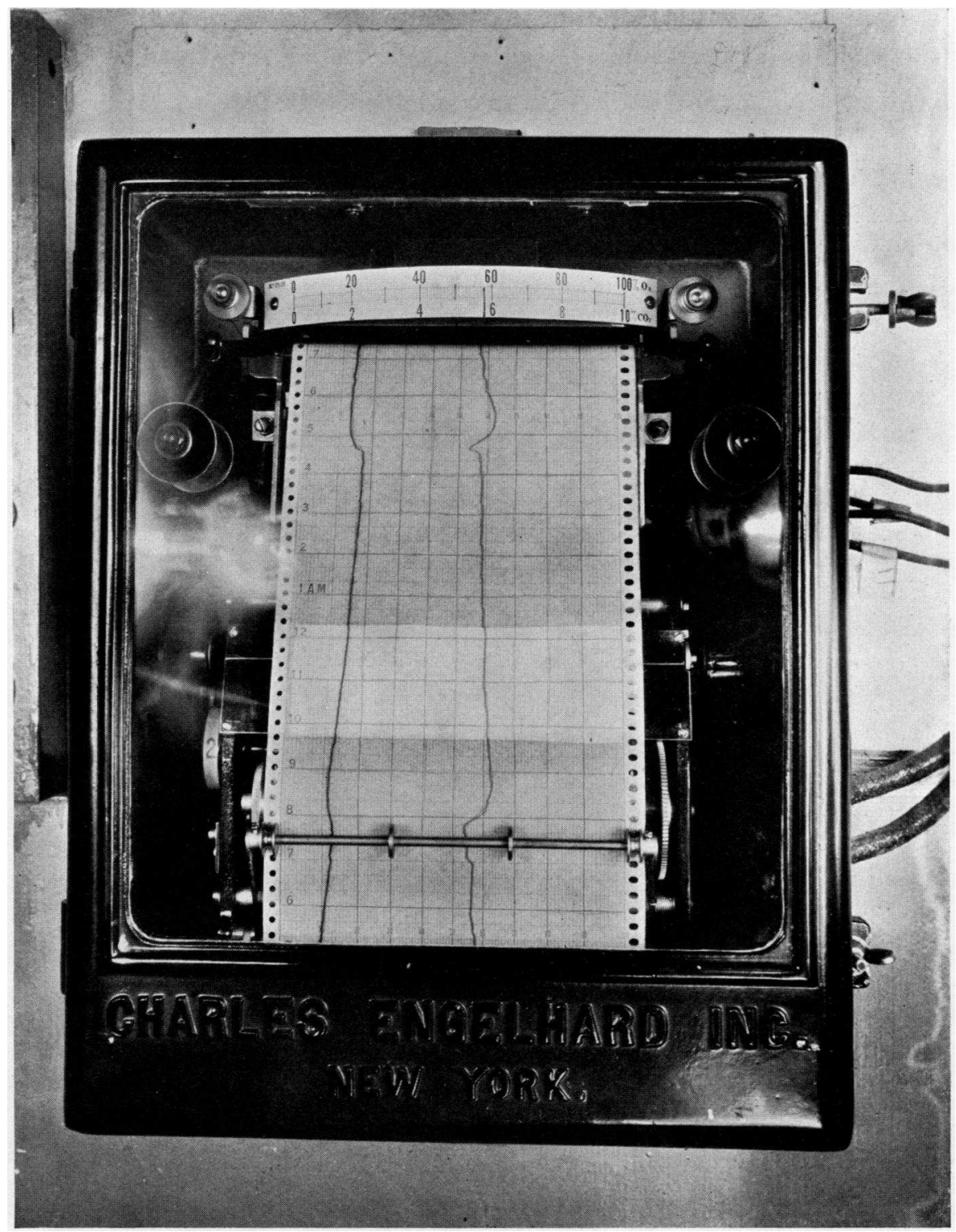

Fig. 3a. Carbon Dioxide and Oxygen Recorder for Atmosphere Control Room at Harlem Hospital: Recording Galvanometer Showing 1.4 Per cent Carbon Dioxide (Heavy Line), and 58 Per cent Oxygen (Lighter Line, Red on Original Chart). 


\section{THE CARBON DIOXIDE AND OXYGEN RECORDER}

Charles Engelhard, Inc., promptly cooperated with us to the extent of constructing and calibrating a recording instrument for both carbon dioxide and oxygen, embodying the principle stated above. The instrument was installed for use at the hospital on February 21, 1930. The double and single by-pass cells, for carbon dioxide and oxygen respectively, and the absorption tubes are shown in Figure 3 attached to a vertical panel on the outer wall of the atmosphere control room. The cells are connected to an especially sensitive 2-point recording galvanometer with a 30 -second alternating contact. The recorder (Fig. $3 a$ ) is attached to the opposite wall, where it is free from disturbing vibrations. The suction pump and batteries are not shown in the photographs.

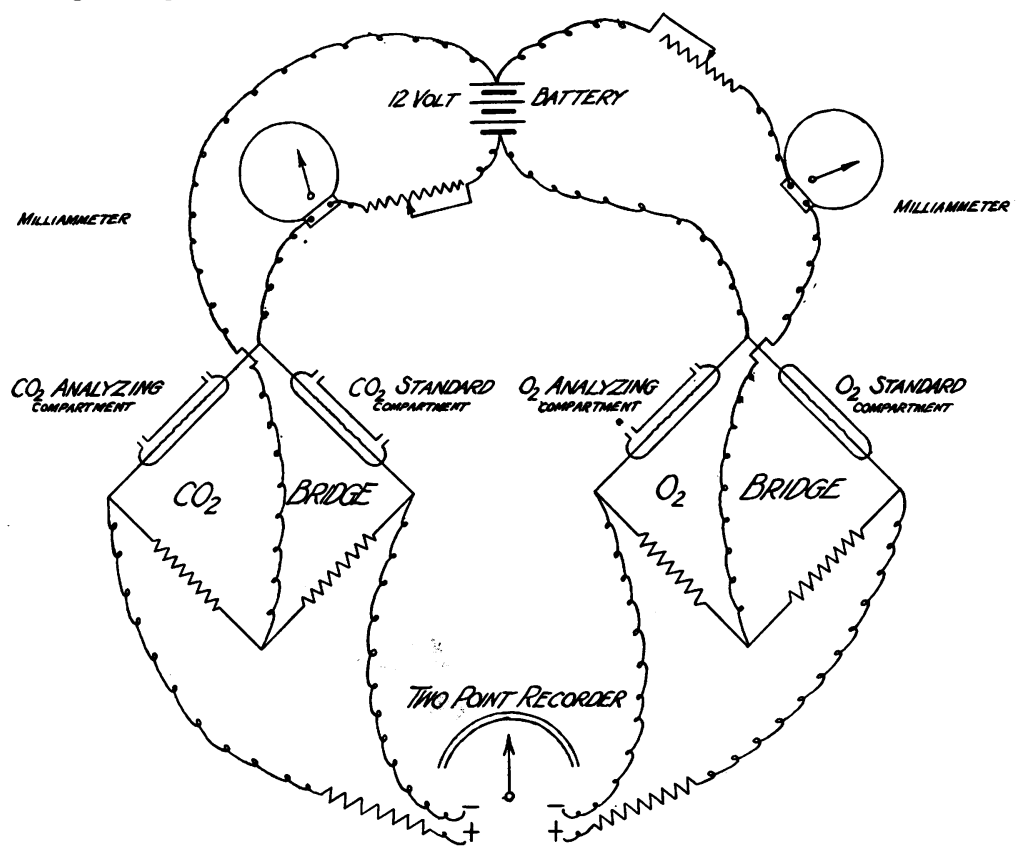

Fig. 4. Carbon Dioxide and Oxygen Recorder. Electrical Diagram

It was found necessary to enclose the single by-pass cell in an air thermostat, which is maintained at $100^{\circ} \mathrm{F}$. by current from the $110-$ volt circuit. This precaution was not necessary in the case of the 
double by-pass cell, which is less sensitive to fluctuations in room temperature. The current through the two bridges, which is maintained at 240 milliamperes by separate milliammeters and rheostats, is supplied by a 12-volt storage battery. The main electrical connections are shown in Figure 4. For charging purposes, two batteries are kept in constant use, one being connected to the recorder while the other is on charge on the 110 D.C. house circuit, the voltage being diminished by $80 \mathrm{ohms}$ series resistance. The change is made daily by the reversal of two double-throw switches. The battery connections are shown in Figure 5. The current for the magnetic

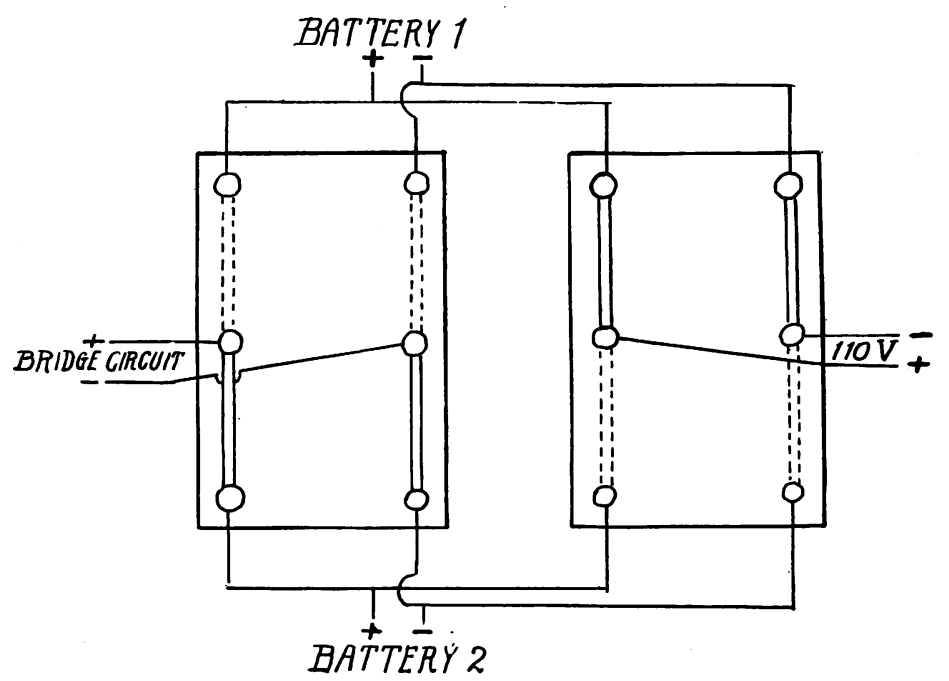

Fig. 5. Battery Connections

Two double-throw switches used for reversing battery connections, one battery being on charge while the other is being discharged through the bridge circuits of the thermal conductivity cells.

alternating contact of the recorder is supplied through a reducing coil from the 110-volt circuit. The small rotary pump, used to maintain a constant flow of gas through the cells, is not shown in the picture. It is lubricated by graphite or Aquadag, since oils are to be avoided in the presence of a high oxygen concentration.

Absorbents. It has been found advisable to depart somewhat from the absorption arrangement described by Hamilton (3) in which sodium 
hydroxide sticks were used as decarbonating agent, and the air to be sampled was dried by calcium chloride before being split into the two streams for the double by-pass cell. In the first place, sodium hydroxide, both in stick and in flake form. seemed poorly adapted for decarbonation of the air stream. The sticks offer insufficient reacting surface and rapidly become coated with carbonate, while, except in the presence of a high carbon dioxide and a low moisture content, the more efficient flakes tend to fuse into a solid mass which clogs the absorption tube.

To overcome this difficulty we substituted soda lime (15 per cent moisture, 4-6 mesh) as decarbonating agent, while retaining calcium chloride of the same mesh for dehydration. In the second place, since the reaction occurs with less efficiency from a thoroughly dried gas, we arranged for division of the gas samples into streams I and II before desiccation, but placed a drying tube after the decarbonating tube in the path of stream II. This arrangement provides for the complete absorption of the water of carbonation formed according to the equation, $\mathrm{CO}_{2}+2 \mathrm{NaOH}=\mathrm{Na}_{2} \mathrm{CO}_{3}+\mathrm{H}_{2} \mathrm{O}$.

Our present scheme is shown in Figure 6. Stream 1 refers to the dehydrated air stream which by-passes the analyzing compartment of the carbon dioxide cell. Stream 2 refers to the decarbonated and dehydrated air stream which by-passes the reference compartment of the carbon dioxide cell and the analyzing compartment of the oxygen cell.

Glass absorption tubes, measuring 18 inches in length and 1 inch in bore, and tapered to a tubular opening at one end, are used in preference to wide tubes or towers since they can be more rapidly replaced and cleaned, and the small bore of the single stopper makes them less liable to leak. The matter of ease in cleaning out the containers is of importance since continuous analysis involves frequent replacement of the absorbents. Thick-walled drying towers of the usual type are troublesome to clean, being readily cracked by the heat developed in dissolving out the partially caked calcium chloride. The drying tubes should be supported in a slanting position with the inlet uppermost, so that the moist calcium chloride flows slowly down the tube and cannot flow back out of the absorption tube to clog the narrow connecting tubes. Large U-tubes could conveniently be used. The absorption tubes should be 
changed when the moisture has advanced one-quarter the length of the tube.

Connections and flow regulation. The connective tubing, T-pieces and stopcocks, shown in Figure 6 , are of copper ( $1 / 4$ inch), all the permanent joints being made with copper couplings coated with aluminum paint. To eliminate loss of oxygen the gas stream is returned from the pump to the chamber from which the sample was drawn. For ease in testing the recorder with room air or with commercial oxygen, or in shifting the connections from one atmosphere control room to another, additional inlet and outlet tubes are provided through

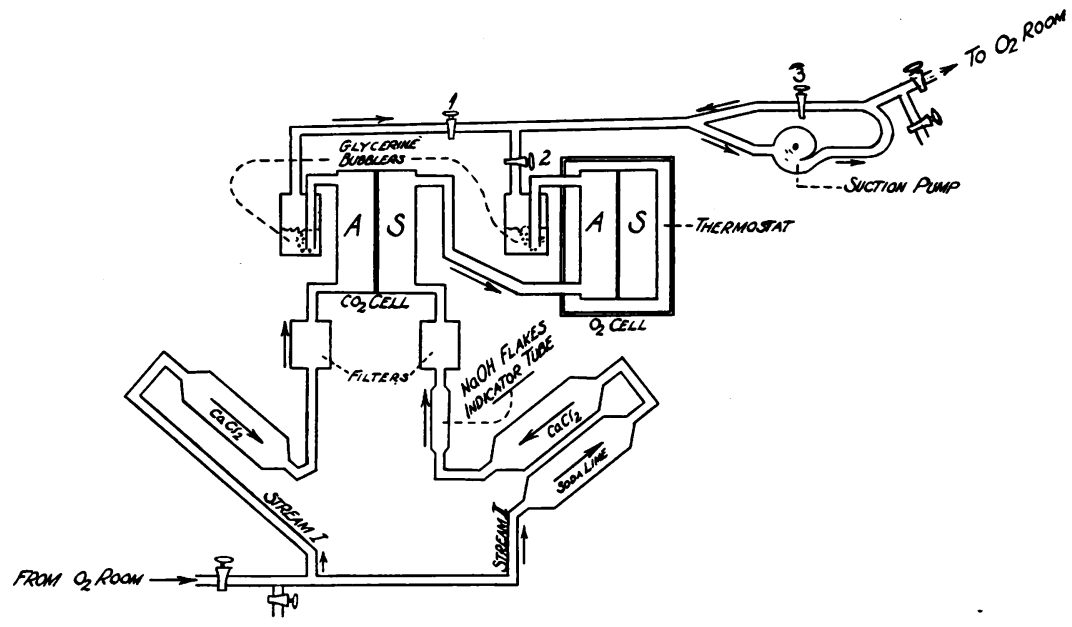

Fig. 6. Flow Diagram of Carbon Dioxide and Oxygen Recorder

$\mathrm{A}$, analyzing compartment of cell. S, standard compartment of cell. $\mathrm{CO}_{2}$ cell: $\mathrm{O}_{2}+\mathrm{N}_{2}+\mathrm{CO}_{2}$ in compartment $\mathrm{A} ; \mathrm{O}_{2}+\mathrm{N}_{2}$ in compartment $\mathrm{S}$. $\mathrm{O}_{2}$ cell: $\mathrm{O}_{2}+\mathrm{N}_{2}$ in compartment $\mathrm{A}$; normal air mixture (dried) in compartment $\mathrm{S}$.

T-piece connections, and the connections to the oxygen chamber can be closed by means of two stopcocks.

As may be seen from Figure 6, the rate of suction may be decreased from the maximum capacity of the pump by partially opening stopcock 3 in a shunt line connecting the inlet to the outlet of the pump. The rate of gas flow for the split streams is further and individually controlled by cocks 1 and 2, and is measured with the aid of glycerine 
bubblers 1 and 2. The rate should be the same in the two streams and should be adjusted to between 80 and 120 bubbles per minute (about $250 \mathrm{cc}$. per minute) since at this rate of flow neither the double nor the single by-pass cell is appreciably sensitive to slight variations in flow rate.

Calibration. In calibrating the instrument at the factory, the

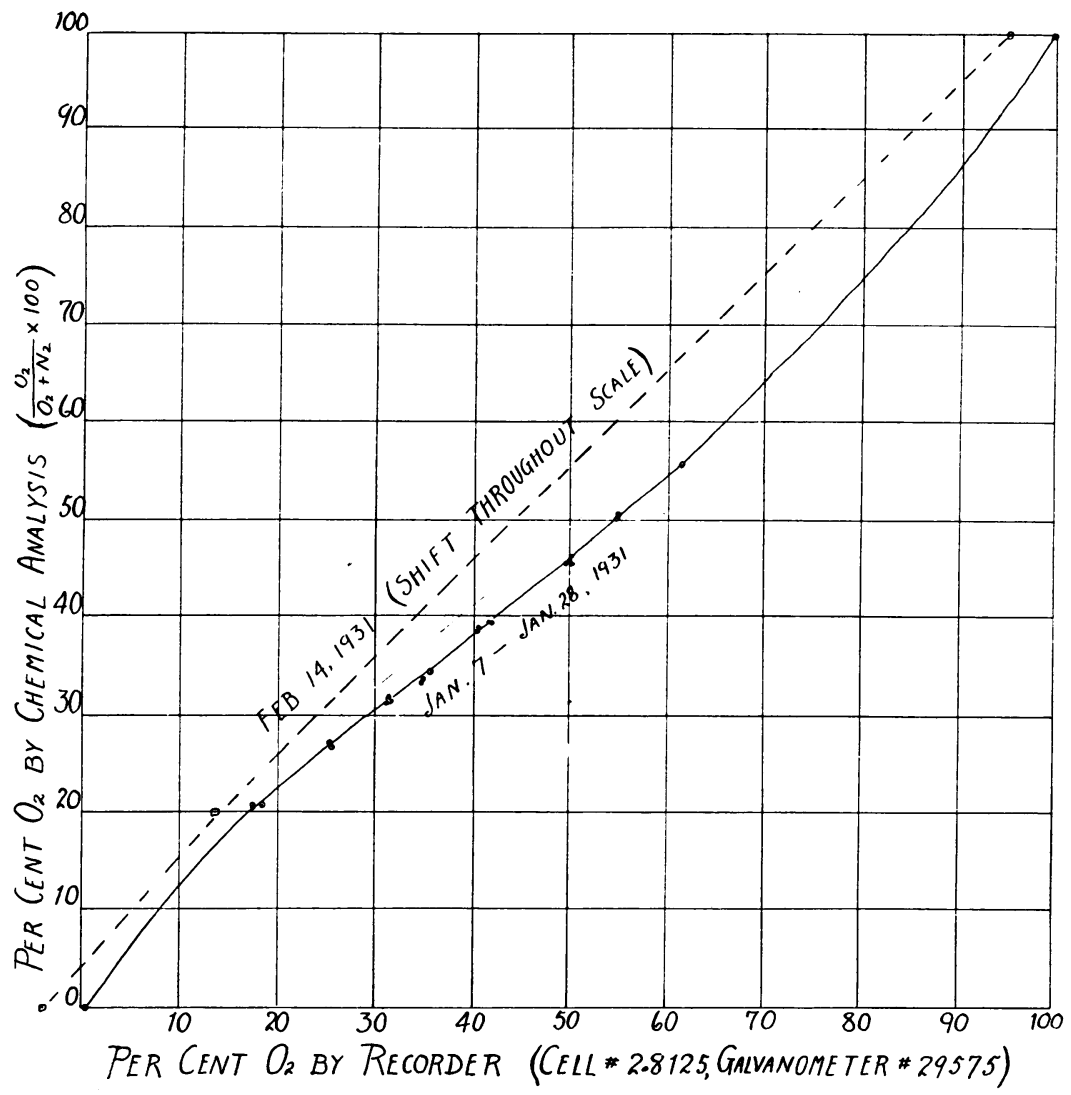

Fig. 7. Calibration Curve for Oxygen

Calibration curve for single by-pass cell no. 28125, showing relation between the per cent scale deflection shown by the recorder and the volume per cent concentration of oxygen in the oxygen-nitrogen mixtures tested. The relation is not linear. The broken curve is drawn through three points obtained after a shift in the scale readings, which is discussed in the text. 
compensating plugs of the two cells were adjusted so as to balance the two bridges (as indicated by zero galvanometer deflection) when both compartments of the double by-pass cell contained carbon dioxide-free and moisture-free room air, and when the single by-pass cell contained dry commercial nitrogen in its analysis compartment. The sensitiveness of each cell was then damped by inserting series resistance in the two circuits connecting the cells to the galvanometer. The resistance was adjusted for the double by-pass cell until the deflection was equivalent in tenths of a full scale to the per cent of carbon dioxide present

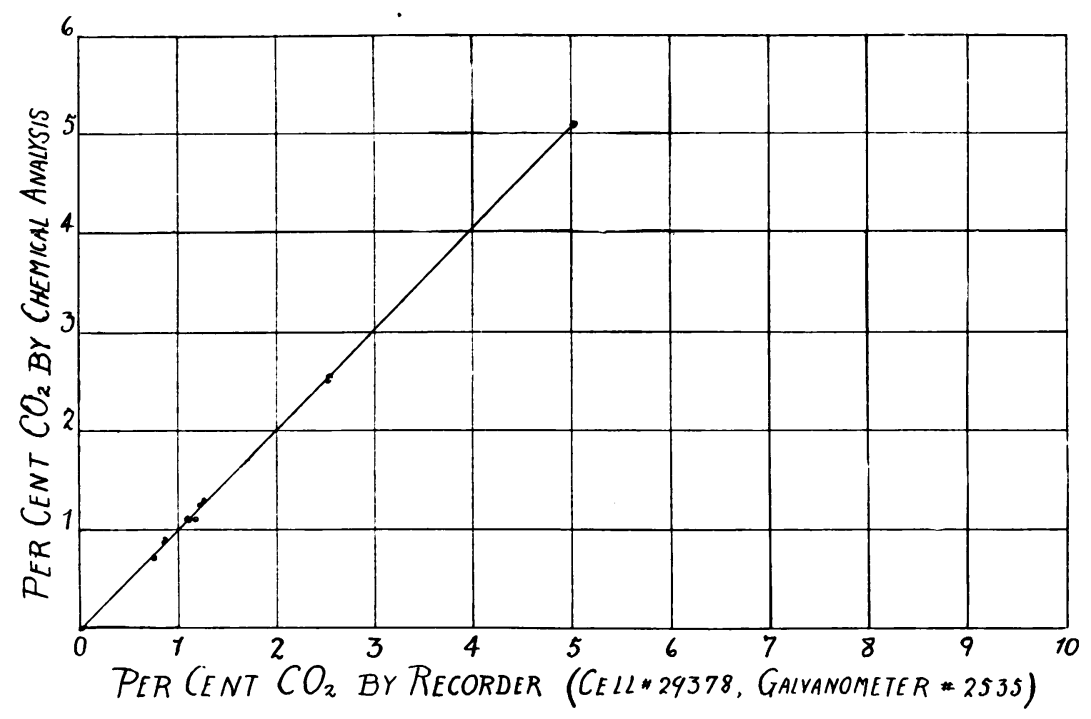

Fig. 8. Calibration Curve for Carbon Dioxide

Calibration curve for double by-pass cell no. 29378, showing relation between per cent scale deflection and the volume per mille concentration of carbon dioxide in the gas mixtures tested. The relation is seen to be linear throughout the range tested.

in a given oxygen-carbon dioxide mixture, and, for the single by-pass cell, until oxygen from a cylinder gave full scale deflection. The deflections obtained from both cells with gas mixtures of lower carbon dioxide and oxygen content were then compared with the values shown by chemical analysis, and the two cells were thus calibrated throughout the range for which they were to be used (3). 
The calibrations were repeated several times after the instrument had been installed at the hospital, the curves obtained (Figs. 7 and 8) being closely similar to those given by Hamilton (3). ${ }^{2}$ Before each calibration test, the zero point of the galvanometer was routinely checked, and the zero point of the cells was tested with nitrogen. In making the latter adjustment we originally used the compensating plug of the cell, described on page 605, but later, at Dr. Hamilton's suggestion, adjusted the balance of the bridge by a slight turn of the slide wire screw provided in the upper part of the cell to change the ratio of the resistance of two arms of the bridge.

Slight variations are to be expected in the calibration curves for the single by-pass cell, depending on the impurities in the compressed nitrogen used in adjusting the zero reading and in the compressed oxygen used in adjusting the galvanometer series resistance for the cell. Indeed, readings taken with different cylinders of oxygen may differ by 1 or 2 per cent. The presence of these impurities (especially hydrogen in the electrolytically prepared commercial oxygen used in these studies, and the rare gases of the atmosphere for the various air mixtures) largely accounts for the $\mathrm{S}$ shape of the oxygen calibration curve. A corrected galvanometer scale can be attached to the instrument to read directly in parts of oxygen per 100 parts of oxygen-nitrogen mixture.

Changes in the thermal and electrical balance of the oxygen cell. Occasional shifts have been observed in the readings given by the single by-pass oxygen cell, the cause for which has not been conclusively determined. A general shift of this sort is shown in Figure 7, in which three check tests taken February 14, 1931, fall to one side of the calibration curve determined from tests on the same cell taken January $7-28,1931$. It will be seen that the instrument gave negative readings for nitrogen (using the same cylinder as in the previous tests) and that the readings for room air and oxygen were similarly displaced downward. Shifts amounting to 2 or 3 and sometimes to 6 or more scale divisions occurred from time to time for the oxygen cell, always in a downward direction. They were usually observed within a month after calibration or adjustment, and, if uncorrected, became progres-

${ }^{2}$ The analytical check tests were carried out by Henry Israel. 
sively greater. In order to correct the cell readings, the Wheatstone bridge was restored to a condition of balance with nitrogen in the analysis compartment by means of the compensating plug at the base of the cell, or preferably by means of the adjusting screw for the bridge resistance wires situated at the top of the cell.

Since persistent and progressive shifts of this type were not observed for the carbon dioxide cell, it seemed possible that the oxygen cell was being contaminated by glycerine spray carried over by the gas stream from the glycerine bubbler which followed the carbon dioxide cell but preceded the oxygen cell in the path of the gas stream. To eliminate this possibility the bubbler was moved (February 16, 1931) to a position following both cells instead of in between the two (Fig. 6). On February 20, the oxygen cell was adjusted by means of the bridge resistance screw so as to read 0 for nitrogen. It then registered 100 for oxygen from a cylinder and between 16.0 and 17.5 for room air, in agreement with the calibration curve determined a month previously. About one month later (March 16) the oxygen cell was reading +0.2 with nitrogen, 99.7 to 101 with oxygen, and 16.6 with room air. On March 17 the reading for room air was 15.5 and on March 20 it was 15.8, while oxygen from a cylinder showed 99.0. No appreciable shift had occurred.

Check tests carried out ten days later revealed a marked downward shift of 5 scale divisions, which we were tempted to attribute to the accidental overheating of the oxygen cell to $180^{\circ} \mathrm{F}$. due to failure of the thermostat control on March 25. The cell was readjusted April 1 , when the shift was observed, and continued to record accurately for over three weeks. Tests with room air and nitrogen on June 3 and 13, however, again showed a downward shift of 3 scale divisions. The cause remains unknown. There has been no interruption of the thermostat control. Since a scale shift has not occurred for the carbon dioxide cell, and since the manufacturers claim that this difficulty has not been elsewhere observed for their single by-pass cells, it may perhaps be attributed to some unknown defect of our particular cell.

Time lag. The time lag associated with the recorder as set up at Harlem Hospital is about 8 to 10 minutes. This lag is partly due to the volume of gas in the absorption and connection tubes and in the bubblers, and partly to the time required for thermal equilibrium to be 
reestablished in the cells after a change in the gas composition. This factor must always be taken into account in interpreting the record, as well as when the instrument index is used as a guide during the purging process or in detecting and compensating oxygen loss due to opening of doors.

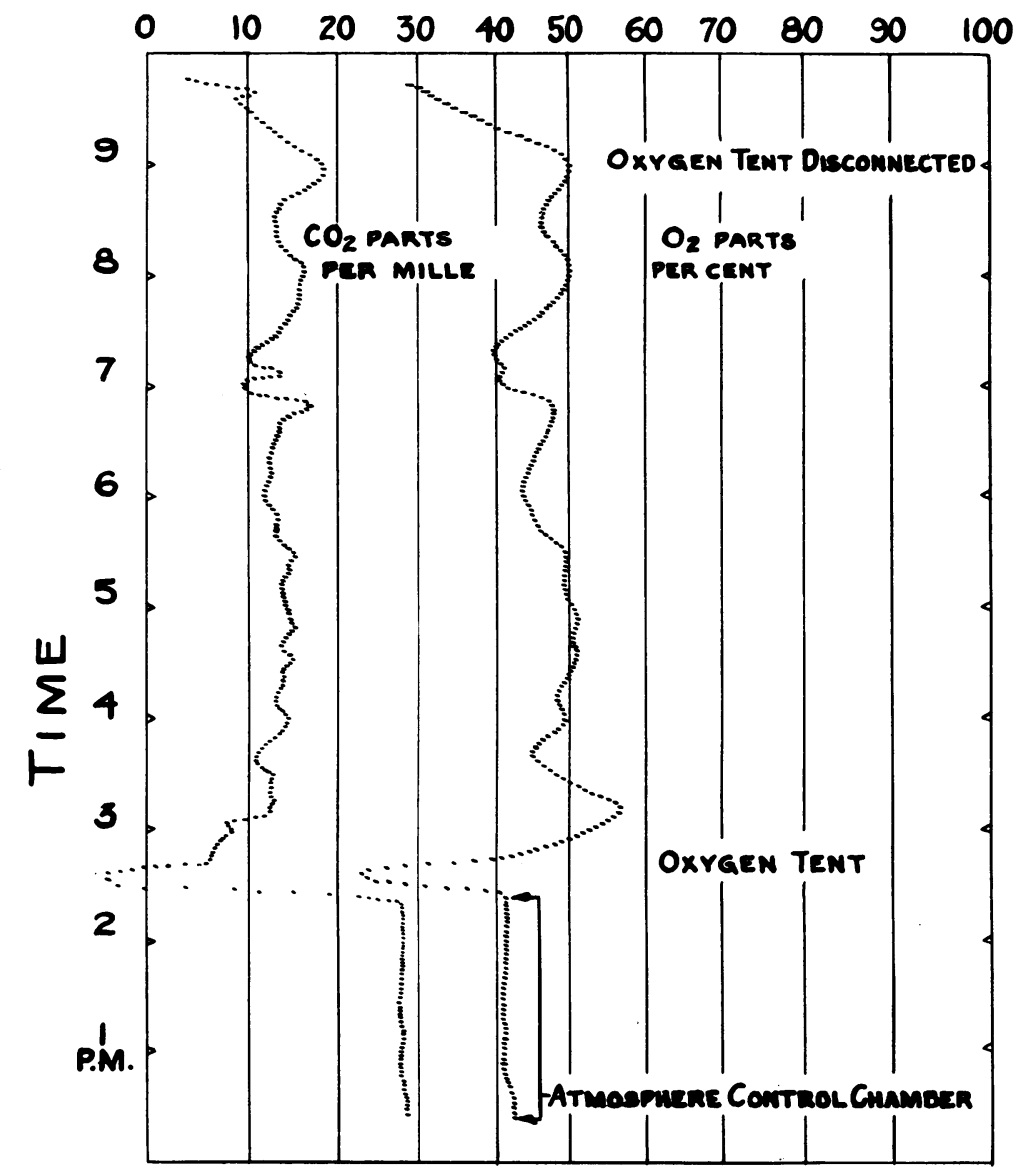

Fig. 9. Sample of Record Sheet of Oxygen and Carbon Dioxide Concentration in Oxygen Chamber and in Oxygen Tent at Harlem Hospital.

Time in hours recorded vertically. Concentration of gas recorded horizontally in terms of volume parts per cent for oxygen uncorrected by calibration curve (recorded at right on chart), and volume parts per mille for carbon dioxide (recorded at left). 
Interpretation of chart. Figure 9 shows a typical sample of recorder chart, obtained when the instrument was connected to the oxygen chamber (12.20 to 2.20 P.M.) and to an oxygen tent (2.40 to 9 P.M.). The time is recorded vertically in hours, each hour being subdivided into 20-minute periods. The concentration of gas is recorded horizontally. The oxygen curve represents volume parts per cent of oxygen-nitrogen mixture (uncorrected for the scale error of the instrument). This curve is recorded on the original record in red. The carbon dioxide curve (recorded in black) represents volume parts per mille of total dry gas mixture. There is no scale correction for this curve.

SOURCES OF ERROR

Faulty readings may be caused by one or more of the following factors:

1. Disturbance of the mechanical zero of the galvanometer. The galvanometer lever is adjusted by means of a screw on top of the recorder case, and should be set so as to read zero when no current is flowing through the galvanometer.

2. Disturbance of the bridge current. The instrument is very sensitive to changes in bridge current, differences of one or two milliamperes being registered as a change in the apparent gas concentration. With proper daily care of the batteries, however, and adjustment of the two bridge rheostats after the daily reversal of the battery switches, the current should not vary appreciably from the correct value of 240 milliamperes.

3. Leaks in the pipe connections. Care must obviously be taken to avoid leakage of air into the cells. To this end the equipment should be assembled with as few tube connections as possible.

4. Exhaustion of the absorbents.

5. General shift throughout the cell readings. This error may be caused by a disturbance of the mechanical zero of the galvanometer, or by a disturbance of the thermal and electric balance of the cell.

6. Inaccurate temperature control by the oxygen cell thermostat.

\section{OPERATING REQUIREMENTS}

The routine care of the batteries, suction pump, absorption tubes and recording mechanism can be assigned to an orderly but the instru- 
ment should be operated under the supervision of a technician familiar with chemical and electrical equipment. It is essential to carry out check tests on the instrument at regular intervals.

\section{Routine care}

1. Absorption tubes (one-half hour to one hour per week). Under our working conditions it has been found necessary to change the absorbents at least twice a week and sometimes daily. The calcium chloride must be renewed when the reaction has extended through onefourth the length of the tube. Since no visible change occurs in the soda lime after reaction, a small $\mathrm{CO}_{2}$-indicating tube containing fresh sodium hydroxide flakes can be placed in the line that includes the soda lime, after the calcium chloride tube, or a few flakes may be placed at the outlet end of this calcium chloride tube. Penetration of moisture will be indicated by liquefaction and fusion of the flakes, and penetration of carbon dioxide by change of the pearly caustic to chalky carbonate.

2. Current control (five minutes daily). The batteries should be tested daily with a hydrometer, to insure a specific gravity of at least 1.215 for the battery connected to the recorder, and to prevent overcharging of the duplicate battery connected to the 110-volt circuit. We reverse the battery switches daily, and, since our rate of charging somewhat exceeds our rate of discharging, we occasionally give each battery a twelve-hour rest period. With these precautions, the bridge current remains very steady, and seldom requires adjustment. When alternating current is available a single battery with a trickle charger can be used.

3. Recorder. The clockwork must be wound once or twice a week, the inked ribbon reversed once every few weeks, and the chart replaced once a month.

4. Suction pump (two hours quarterly). If the recorder is to be used with high concentrations of oxygen, the rotary pump should not be lubricated with oil because of the resulting fire hazard. Glycerine is an unsatisfactory lubricant, tending to char, and clog the bearings. Aquadag, an aqueous suspension of graphite, can be used, but similarly causes the bearings to become clogged from time to time. We have found undiluted graphite to be the most dependable lubricant. The pump must be cleaned out once every few months. 


\section{Periodic tests}

It is recommended that the supervising technician carry out the following tests. All tests should be preceded by routine examination of the mechanical zero of the galvanometer, of the bridge current and of the temperature of the oxygen cell thermostat.

1. Once a week the recorder should be allowed to analyze a sample of ordinary room air, in which case the carbon dioxide should read 0 to 0.1 per cent and the oxygen should read 20 to 21 per cent on the corrected scale (or 16 to 18 per cent on the uncorrected scale). This test is useful as an indication of a general displacement or shift in the recorder readings for one or both cells (see paragraphs 1 and 5 of the section headed Sources of Error). It gives little or no information regarding leakage, since the air in the cells is closely similar to that surrounding the pipes and connections.

2. If one of the cells gives a correct reading but the reading for the other cell is appreciably displaced from the correct value, this cell should be tested for a general shift (see pages 620 and 621 and paragraph 5 of the section headed "Sources of Error"). The oxygen cell, which was the cell for which we observed an occasional unexplained shift, can be tested most readily by stopping the suction pump and forcing dried nitrogen or dried oxygen through the cells at the usual rate $(80$ to 120 bubbles per minute through each bubbler, or less than one liter per minute for the combined streams) from a cylinder provided with a hospital flow regulator. If no shift has taken place, and the error was due to leakage into the oxygen cell under suction, the oxygen cell of the recorder will then register 0 with nitrogen and 100 with oxygen. If a shift has taken place. the readings with room air, with oxygen and with nitrogen will show parallel discrepancies from the calibration curve, as are shown in Figure 7 by the oxygen readings for February 14. It is advisable to notify the manufacturers if the cell readings show a tendency to shift, rather than to correct the shift whenever discovered by adjustment of the compensating plug or the bridge resistance of the single by-pass cell.

3. At least once a month the recorder should be checked by chemical analysis of the air sample. The Haldane absorption burette is accurate only up to 40 per cent of oxygen. We have obtained satis- 
factory results with the absorption apparatus shown in Figure 10, which is adapted to oxygen and carbon dioxide analysis to within \pm 0.1 per cent, the oxygen range extending from 0 to 65 parts per 100 parts of oxygen-nitrogen mixture. This apparatus is portable and

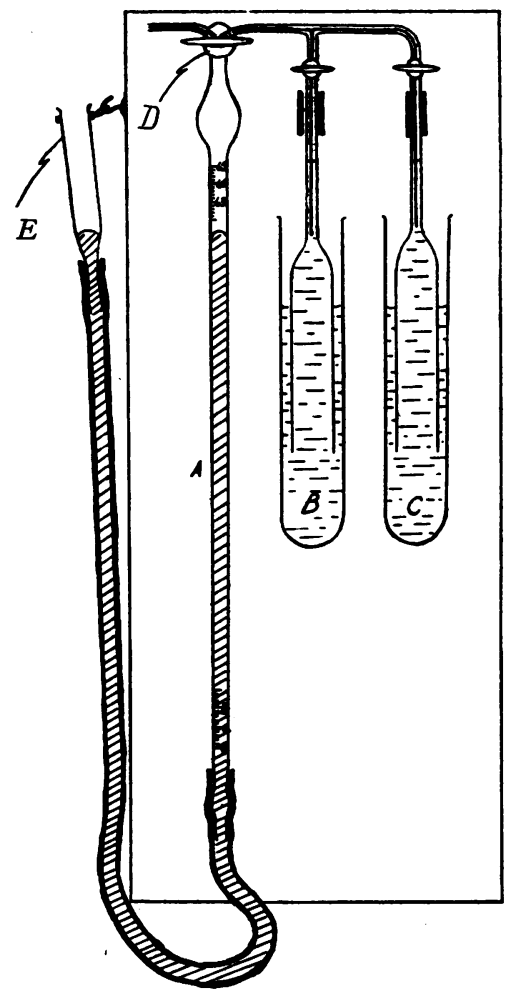

Fig. 10. Gas Analysis Apparatus for Carbon Dioxide and Oxygen, for Concentrations from 0 to 65 Volumes Per cent

A, burette holding $12 \mathrm{cc}$. of gas, graduated 0-65 per cent, in 0.2 per cent divisions. B, absorption pipette for oxygen. C, absorption pipette for carbon dioxide. D, three-way stopcock. E, levelling bulb with mercury.

inexpensive. We use a 20 per cent solution of potassium hydroxide for the carbon dioxide, and for oxygen absorption sodium hydrosulphite, the reaction being accelerated by sodium anthrahydroquinone $\beta$-sulphonate, as recommended by Van Slyke (10).

The readings on the corrected scale should agree with the chemical 
analysis to within \pm 0.15 per cent for carbon dioxide and \pm 1.5 per cent for oxygen.

If the instrument is inaccurate by 0.2 per cent or more for the carbon dioxide readings or by 2.0 per cent or more for the oxygen readings, the cells should be tested for a shift throughout the scale, using room air and tank oxygen or nitrogen, as discussed above in paragraphs 1 and 2. If parallel discrepancies do not appear throughout the scale, the error is probably due to exhaustion of the absorbents or to leakage. The chemical check tests should then be repeated after renewing the absorbents, resealing all permanent connections with paint, and renewing all rubber connections. It should be stressed that leakage of outside air into the cells will not result in a positive error for the oxygen readings unless the air sample under test contains less oxygen than ordinary room air. The presence of water vapor in the oxygen cell (exhaustion of the drying agent) may, however, slightly raise the apparent oxygen reading (2). The presence of carbon dioxide in the oxygen cell (exhaustion of the decarbonating agent when the gas sample is rich in carbon dioxide) will lower the apparent oxygen reading. Leaks into the double by-pass carbon dioxide cell may cause either a positive or a negative error.

\section{USE OF KATHAROMETER FOR INDICATION OF OXYGEN AND CARBON DIOXIDE IN AIR}

A "katharometer" capable of indicating from 0 to 10 parts of carbon dioxide in air was put at our disposal for preliminary study through the courtesy of the Cambridge Instrument Co. Out tests showed that this single by-pass thermal conductivity instrument can also be adapted as an oxygen in air indicator.

Since the katharometer is not equipped as is the Engelhard instrument with a mechanical means for balancing the two compartments of the thermal cell, nor with a bridge slide-wire adjustment, the galvanometer will show a zero deflection only when analysis and reference compartments contain thermally identical gas mixtures. With dry room air in the reference compartment, and the galvanometer leads reversed from the usual position for carbon dioxide indication, the instrument indicates an excess in oxygen concentration over the normal 21 per cent. The sensitiveness in terms of scale deflection per volume 
per cent change in concentration is for oxygen about $1 / 10$ of that for carbon dioxide. Thus, whereas full scale deflection in one direction is registered for a mixture containing the normal oxygen-nitrogen balance plus 10 per cent carbon dioxide, tank oxygen, containing 79 per cent more oxygen than ordinary air, gives between 70 and 80 per cent of a full scale deflection in the opposite direction. Oxygen deficiencies (concentrations of less than 21 per cent) will show a positive deflection when the galvanometer is connected as for carbon dioxide indication.

It will be seen that the instrument can be made to function as both oxygen and carbon dioxide indicator for mixtures in which both gases vary independently. To this end the reference compartment is filled with dry room air, the galvanometer leads are connected to a reversing switch, and consecutive tests are carried out with a gas sample that is both dried and decarbonated and with another sample of the same gas that is dried but not decarbonated. The concentration of oxygen, in volume parts per cent of the oxygen-nitrogen mixture, will be given by adding 21 to the number of per cent scale divisions deflected in the first galvanometer reading, counting the galvanometer reading as positive when the leads are connected as to indicate pure oxygen, and negative when the leads are reversed as to indicate pure nitrogen. The carbon dioxide concentration of the mixture, in parts per mille, will be given by subtracting the second reading from the first reading, using the same convention as to the sign of the galvanometer reading. For example, if the first reading should be -5 , and the second reading -45 per cent of a full scale deflection, the oxygen concentration would be $21-5$, or 16 per cent, and the carbon dioxide concentration would be $-5-$ $(-45)$, or 40 parts per mille.

We did not attempt to calibrate the katharometer for oxygen determinations nor to check closely the constancy and reproducibility of its readings.

Out tests with the katharometer led us to question the present method of attempting to balance the water vapor in the two compartments of the thermal cell by saturating the air samples in both compartments, instead of by eliminating the water completely. The instrument is used largely for carbon dioxide determinations of alveolar air, which is presumably saturated with water vapor at about $35^{\circ} \mathrm{C}$. The 
closed reference compartment, on the other hand, is provided with a moist wick which maintains a saturated atmosphere at an unknown temperature, probably very close to room temperature. The temperature effect on the saturation concentration of the two air samples appears to have been overlooked.

In determining the zero reading of the cell the analysis compartment is fitted with ordinary room air, moistened by bubbling through water. The resulting partial pressure of water vapor will depend on the temperature and on the degree of saturation obtained by the bubbling method, and it may readily vary from 15 to $24 \mathrm{~mm}$. of mercury, corresponding to from 2 to 3 per cent by volume. The water vapor in the sealed compartment with the moist wick will correspond to that in the analysis compartment only if the temperature and the degree of saturation coincide. Certainly the partial pressure of water vapor in a sample of alveolar air differs from that of room air. Assuming the sample to be saturated with moisture at $35^{\circ} \mathrm{C}$., the water vapor would exert a pressure of $41 \mathrm{~mm}$. of mercury, and its concentration by volume be about 5.5 per cent.' If variations of about 1 or 2 per cent in the volume concentration of water vapor affect appreciably the thermal conductivity of air, the katharometer readings would be in error unless water were completely removed from both compartments. At the same time, the thermal effect of water vapor, as estimated by two independent methods, appears to be definitely appreciable.

From the data of Gruss and Schmick (2) a 7 per cent water-air mixture has at $80^{\circ} \mathrm{C}$. a thermal conductivity equal to that of dry air multiplied by the factor 1.02. Eucken's value for the thermal conductivity of dry air at $100^{\circ} \mathrm{C}$. is $71.9 \times 10^{-6}$ (Table 1 ). On the assumption that the same ratio holds at this temperature, a 7 per cent water-air mixture at $100^{\circ} \mathrm{C}$. would have a thermal conductivity of $73.3 \times 10^{-6}$. If we make the further assumption of a linear relation between thermal conductivity and water vapor concentration within the range 0 to 7 per cent, the thermal conductivity of air will be increased by $1.4 \times 10^{-6} / 7$ or by $0.2 \times 10^{-6}$ per per cent increase in water vapor for this range. The difference between the thermal conductivity of dry air and of carbon dioxide is $22.3 \times 10^{-6}$ at $100^{\circ} \mathrm{C}$. (Table 1). If we assume a linear relation between thermal conductivity and concentration for carbon dioxide in air mixtures, we find that the thermal conductivity of air is decreased by $22.3 \times 10^{-6} / 100$ or by $0.2 \times 10^{-6}$ per per cent increase in carbon dioxide. Therefore the effect of differences in water vapor concentration in terms of volume per cent 
should for this region be of the same order of magnitude as that of differences in carbon dioxide concentration.

This estimate is in agreement with the results of a test in our laboratory on the effect of water vapor in low concentrations, using the Engelhard double by-pass (carbon dioxide) cell. Since water vapor, in concentrations up to about 20 per cent, increases the thermal conductivity of air while carbon dioxide decreases it, the galvanometer leads to the Wheatstone bridge were reversed from their normal position for carbon dioxide. Dried room air was admitted to both compartments of the cell until a constant galvanometer reading had been obtained. The calcium chloride tube was then disconnected from the air stream leading to the analysis compartment and when conditions had again become steady a second reading was taken. This reading was exactly 10 scale divisions higher than the first, a displacement equal in magnitude (though opposite in sign) to that caused by an increase in carbon dioxide from 0 to 1 per cent. Wet and dry bulb thermometer readings were 57.4 and 69.2 respectively, indicating a partial pressure of $8.6 \mathrm{~mm}$. of mercury due to water vapor, or a concentration of about 1.1 per cent water vapor.

Since the effect of water vapor in low concentrations thus appears to be of about the same order of magnitude as that of carbon dioxide, it is not clear how the neglect of moisture differences in the use of the katharometer for alveolar air studies can be compatible with accurate results.

\section{SUMMARY}

1. Continuous gas analysis is recommended as an aid in clinical atmosphere control.

2. A review is presented of the theory of quantitative gas determinations by the thermal conductivity method.

3. The difficulties attending the application of the thermal conductivity method of analysis to oxygen and carbon dioxide in air mixtures are discussed.

4. Tests are presented leading to the adoption of a double by-pass thermal cell for carbon dioxide in air measurements, and of a single by-pass cell for oxygen in air measurements.

5. The Engelhard carbon dioxide and oxygen recorder is described in detail.

6. Sources of error are enumerated.

7. Operating requirements and control tests are listed and described. 
8. The adaptability of the "katharometer" for oxygen analysis is discussed.

\section{BIBLIOGRAPHY}

1. Bullowa, Jesse G. M. and Lubin, Grace, Am. J. Med. Sci., 1931, clxxxi, 560. The Advantages for an Atmosphere Control Room of a QuasiContinuous Record of Oxygen and Carbon Dioxide.

2. Grüss, Heinz and Schmick, Hans, Wiss. Veröffentlich. aus dem SiemensKonzern., 1928, vii, 202. Über die Wärmeleitfähigheit von Gasgemischen.

3. Hamilton, Wm. F., J. Ind. and Eng. Chem., 1930, ii, 233. Industrial Analysis and Recording of Carbon Dioxide and Oxygen in Air.

4. Hill, A. V., Proc. Physiol. Soc., J. Physiol., 1922, lvi, xx. An Electrical Method (Katharometer) for Measuring the $\mathrm{CO}_{2}$ in Respired Gases.

5. Knipping, H. W., Ztschr. f. Physiol. Chem., 1924, cxli, 1. Über die Bestimmung der Kohlensäurespannung in der Alveolarluft.

6. Ledig, Paul G. and Lyman, R. S., J. Clin. Invest., 1927, iv, 495 . An Adaptation of the Thermal Conductivity Method to the Analysis of Respiratory Gases.

7. Lubin, Grace and Bullowa, Jesse G. M., Proc. Soc. Exp. Biol. and Med., 1930, xxvii, 568. A Thermal Conductivity Recorder for Oxygen and Carbon Dioxide for Clinical Atmosphere Control.

8. Palmer, P. E. and Weaver, E. R., Tech. Papers Bur. Standards, 1924, ccxlix. Thermal Conductivity Method for the Analysis of Gases.

9. Rabinowitch, I. M. and Bazin, E. V., J. Can. Med. Assoc., 1926, xvi, 638. A Simple and Accurate Method of Determining Basal Metabolic Rates. An Electrometric (Katharometer) Procedure.

10. Van Slyke, Donald D., J. Biol. Chem., 1927, lxxiii, 121. Note on a Portable Form of the Manometric Gas Apparatus and on Certain Points in the Technique of its Use. 